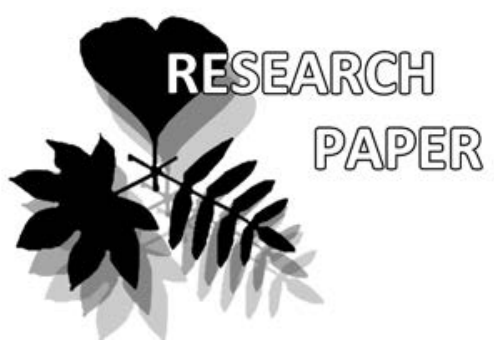

\title{
In vitro Barnardia japonica (Thunb.) Schult. et Schult. fil. micropropagation by direct regeneration
}

\author{
Anastasiya S. Pianova (Berdasova), Aleksey V. Salokhin, \\ Tat'yana E. Lonchakova \& Yuri E. Sabutski*
}

Anastasiya S. Pianova (Berdasova) e-mail: berdasova_as@mail.ru

Aleksey V. Salokhin

e-mail: al-xv@mail.ru

Tat'yana E. Lonchakova

e-mail: yashma135@mail.ru

Yuri E. Sabutski*

e-mail: alixar2006@yandex.ru

Botanical Garden-Institute FEB RAS Vladivostok, Russia

* corresponding author

Manuscript received: 01.09.2021

Review completed: 25.10.2021

Accepted for publication: 29.10.2021

Published online: 30.10.2021

\begin{abstract}
A B S T R A C T
In vitro micropropagation of rare Far Eastern species Barnardia japonica by the direct regeneration method was studied for the first time. The effect of different concentrations of 6-benzylaminopurine and kinetin in combination with auxins on the regeneration potential of young seedlings using Murashige and Skoog media was estimated. It was found that the largest number of new plants (61 new shoots on average) is formed when explants are cultivated on the medium with a high concentration of kinetin $(10 \mathrm{mg} / \mathrm{L})$ and a minimum of $\alpha$-naphthylacetic acid $(0.1 \mathrm{mg} / \mathrm{L})$. The resulting plants are rooted easily on a hormone-free medium of the same mineral composition. The least effective for the mass production of plants by direct regeneration was a medium with a combination of $2 \mathrm{mg} / \mathrm{L}$ kinetin and $1 \mathrm{mg} / \mathrm{L}$ $\alpha$-naphthylacetic acid. The developed approach can be applied for the effective propagation of Barnardia japonica and returning the species to its natural habitat.
\end{abstract}

Keywords: in vitro culture, micropropagation, regeneration, Scilla scilloides, conservation

\section{P E 3 Ю M E}

Пьянова (Бердасова) А.С., Самохин А.В., Аончакова Т.Е., Сабуцкий Ю.Е. Микроразмножение Barnardia japonica (Thunb.) Schult. et Schult. fil. методом прямой регенерации в культуре in vitro. Методом прямой регенерации в культуре in vitro впервые исследовано микроклональное размножение Barnardia japonica - виАа, находящегося в РФ на грани исчезновения. Изучено влияние размичных концентраций 6-бензиламинопурина и кинетина в комбинации с ауксинами на регенерационный потенциал молодых сеянцев с использованием в качестве базальной среды компонентного состава по прописи Murashige и Skoog. Найдено, что наибольшее число новых растений (в среднем 61 новый побег) образуется при культивировании эксплантов на среде с высоким содержанием кинетина $(10 \mathrm{мг} / \Lambda)$ и минимальным $\alpha$-нафтилуксусной кислоты $(0.1 \mathrm{мг} / \Lambda)$. Полученные растения Аегко укореняются на безгормональной среде того же минерацьного состава. Наименее эффективной Аля массового получения растений путем прямой регенерации была среда с использованием сочетания

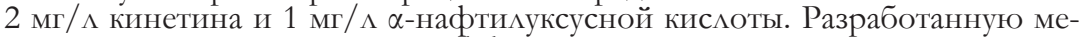
тодику можно применять Аля эффективного размножения и возвращения вида в его естественные условия об̆итания.

КАючевые слова: микроразмножение, регенерация, пролеска, Scilla scilloides, coхранение
Barnardia japonica (Scilla scilloides (Lindl.) Druce) is a perennial bulbous autumn-flowering plant of the family Hyacinthaceae. It is distributed mainly in Northeastern China, Japan and the Korean Peninsula (Ohwi 1965, Kitagawa 1979, Lee 1993, Lee 1996). On the territory of the Russian Far East, there is the northern border of the species distribution. It was considered as disappeared from the flora of Russia for a long time (Barkalov 2008). Recently discovered populations in the Khasansky District and on Sakhalin Island made it possible to change the rarity category from 0 (EX) to 1 (CR) (Goncharova et al. 2013, Pshennikova et al. 2019).

The experience of cultivating Barnardia japonica in the Botanical Garden-Institute FEB RAS indicates its stability in culture. Late flowering and re-vegetation since August give a special decorative effect. However, even in culture, the indicators of seed reproduction (the coefficient of fruitfulness, the percentage of seed production, potential and real seed productivity) are quite low, which probably explains the rarity of detection in natural habitats (Goncharova et al. 2013).

An alternative preservation method and an effective reproduction technique is the study of cultivation and micropropagation processes in vitro. There are many works devoted to the tissue culture exploration of the genus Scilla L. representatives (McCartan \& van Staden 1998, McCartan \& van Staden 1999, Barykina \& Churikova 2001, Chaudhuri \& Sen 2002, Banciu et al. 2010). Fragments of bulbous scales and leaves are mainly used as explants for obtaining a sterile culture (Nair 1989, McCartan \& van Staden 1998, Kamaleswari et al. 2016), however, due to frequent deep fungal and bacterial infections, it is possible to use floral 
explants and flower stalk fragments (Chakravarty \& Sen 1989, Ozdemir et al. 2016).

Earlier, Korean scientists obtained an embryogenic callus of Barnardia japonica from plants of various cytogenetic types and have studied the somaclonal variability of the resulting regenerated plants (Bang \& Choi 1996). It was found that somaclonal variability was determined by the cytogenetic type and ploidy level of the original plants. In some cases, the percentage of the variability was very high and reached $87.7 \%$. It is known that micropropagation using the direct regeneration method minimizes the possibility of somaclonal variability of the resulting regenerated plants (Butenko 1999) which allows preserving their genetic uniformity and use them to restore populations of certain cytogenetic types. Also in the work of Romanian scientists (Banciu et al. 2010) was shown that Scilla autumnalis L. plants obtained by the direct regeneration did not have any genetic changes. Our work aimed to establish optimal conditions for effective in vitro micropropagation of B. japonica by direct regeneration.

\section{MATERIAL AND METHODS}

Mature seeds of B. japonica were collected in 2016 near settlement Zarubino (Khasansky District of Primorye Territory) and used as a starting material for obtaining a sterile culture in vitro. To study the micropropagation process we used two-month-old young seedlings containing 2 leaves and a formed bulb with removed roots. The number of explants in each experiment is 10 , the number of repetitions is 3 .

For the preparation of nutrient media, we used extra pure grade (LenReaktiv, Russia) macro- and microelements according to Murashige-Skoog composition (Murashige \& Skoog 1962), sucrose (Helicon, Russia), phytohormones (Sigma-Aldrich, USA), vitamins and agar-agar (SigmaAldrich, USA). Silver nitrate (LenReaktiv, Russia) was used for the seeds sterilization.

Preparation and sterilization of the media were performed according to standard procedures (Butenko 1999). The solutions were adjusted to $\mathrm{pH} 5.7-5.8$ using $0.1 \mathrm{~N} \mathrm{KOH}$ before autoclaving. Sucrose concentration in all cases was $3 \%$, agar $0.6 \%$. Plant hormones and vitamins added after autoclaving. The media were poured into sterile test tubes $(10 \mathrm{~mL}$ of the media) or $250 \mathrm{~mL}$ Erlenmeyer flask $(50 \mathrm{~mL}$ of the media).

The seeds were pre-soaked for 24 hours before sowing and then washed for 20 minutes in a $0.1 \%$ Tween 80 solution. Surface sterilization was carried out using a $1 \%$ silver nitrate solution (exposure time $15 \mathrm{~min}$ ) followed by a single wash with $1 \%$ sterile sodium chloride solution and twice with sterile distilled water ( 2 minutes each). The seeds were placed on an agarized hormone-free Murashige and Skoog (MS) medium (Murashige \& Skoog 1962) and germinated for 4 weeks. One month after germination the plants were transplanted onto a new medium. At the stage of micropropagation, various combinations of cytokinins (6-benzylaminopurine (BAP), 6-furfurylaminopurine or kinetin $(\mathrm{Kn})$ ) and auxins (2,4-dichlorophenoxyacetic acid (2,4-D), $\alpha$-naphthylacetic acid (NAA), indole-3-butyric acid (IBA)) were added to the nutrient medium at concentrations of 0.1-10.0 $\mathrm{mg} / \mathrm{L}$ to induce shoot formation. The medium without growth regulators used as a control. Subsequent subculturing of explants on the fresh medium of the same composition was carried out every $3-4$ weeks. The rooting of the resulting regenerated plants took place in flasks using a hormone-free MS medium. The experiments were carried out in 3 repetitions. Conditions for seed germination and explants cultivation: temperature $24 \pm 2^{\circ} \mathrm{C}, 16$-hour photoperiod, illumination of 2000-3000 lux with coolwhite fluorescent light (Philips, Poland).

Statistical processing and analysis of the data were performed using Statistica 6.1 software.

\section{RESULTS}

At the stage of sterile culture obtaining we showed $100 \%$ efficiency of the B. japonica seed sterilization technique with $1 \%$ silver nitrate solution. Mass germination of seeds on hormone-free MS medium was observed on the 13th day of cultivation. The average percentage of seed germination after 30 days was $85.7 \%$.

In our experiments, we used young seedlings as explants at the stage of two true leaves with formed bulbs and removed roots. To study the type of seedlings morphogenetic response, the resulting plants transferred to MS medium containing various combinations of cytokinins and auxins: $2 \mathrm{mg} / \mathrm{L} \mathrm{BAP} \mathrm{+} 1 \mathrm{mg} / \mathrm{L} \mathrm{NAA}, 4 \mathrm{mg} / \mathrm{L} \mathrm{BAP} \mathrm{+}$ $1 \mathrm{mg} / \mathrm{L} \mathrm{NAA}, 2 \mathrm{mg} / \mathrm{L} \mathrm{BAP}+0.5 \mathrm{mg} / \mathrm{L} \mathrm{IBA}, 2 \mathrm{mg} / \mathrm{L} \mathrm{NAA}$ $+0.5 \mathrm{mg} / \mathrm{L}$ BAP, $1 \mathrm{mg} / \mathrm{L} 2,4-\mathrm{D}+0.5 \mathrm{mg} / \mathrm{L}$ BAP, $2 \mathrm{mg} / \mathrm{L}$ $\mathrm{Kn}+1 \mathrm{mg} / \mathrm{L} \mathrm{NAA}$ and $10 \mathrm{mg} / \mathrm{L} \mathrm{Kn}+0.1 \mathrm{mg} / \mathrm{L} \mathrm{NAA}$.

When we used media with a higher concentration of auxin than the concentration of cytokinin, the process of direct regeneration was observed only in the case of combination $2 \mathrm{mg} / \mathrm{L} \mathrm{NAA}$ and $0.5 \mathrm{mg} / \mathrm{L} \mathrm{BAP}$. After 2 months of cultivation, adventitious shoots were formed on the surface and at the base of the explants. This process was accompanied by an increase in the size of the explants and the formation of dense morphogenic callus tissue (Fig. 1A). After the resulting callus was transferred to a hormone-free media, active regeneration of shoots was observed. Replacement of NAA by 2,4-D at a concentration of $1 \mathrm{mg} / \mathrm{L}$ led only to a pronounced callusogenesis of the explants with the formation of a dense white callus (Fig. 1B). Cultivation of the

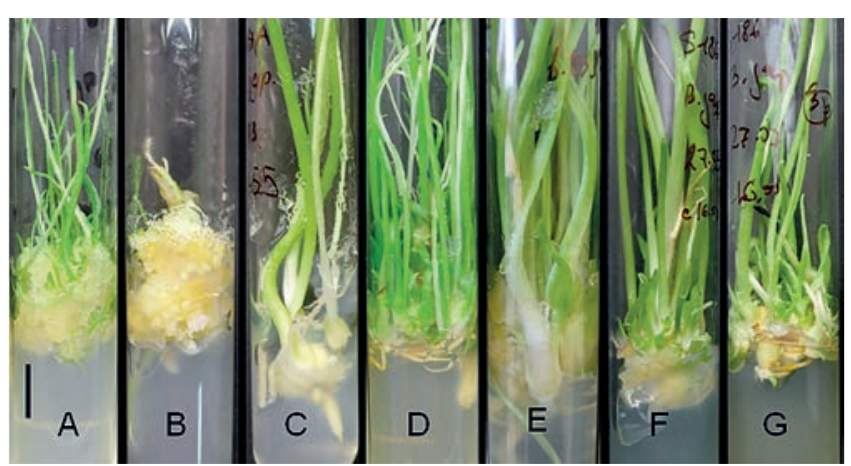

Figure 1 Types of Barnardia japonica seedlings morphogenetic response on MS media with different composition of cytokinins and auxins after 3 months of cultivation: A - media with $2 \mathrm{mg} / \mathrm{L} \mathrm{NAA}$ and $0.5 \mathrm{mg} / \mathrm{L}$ BAP; B - media with $1 \mathrm{mg} / \mathrm{L} \mathrm{2,4-D} \mathrm{and} 0.5 \mathrm{mg} / \mathrm{L} \mathrm{BAP;} \mathrm{C} \mathrm{-} \mathrm{media}$ with $2 \mathrm{mg} / \mathrm{L} \mathrm{Kn}$ and $1 \mathrm{mg} / \mathrm{L}$ NAA; D - media with $10 \mathrm{mg} / \mathrm{L} \mathrm{Kn}$ and $0.1 \mathrm{mg} / \mathrm{L}$ NAA; E - media with $2 \mathrm{mg} / \mathrm{L}$ BAP and $1 \mathrm{mg} / \mathrm{L}$ NAA; F media with $4 \mathrm{mg} / \mathrm{L} \mathrm{BAP}$ and $1 \mathrm{mg} / \mathrm{L} \mathrm{NAA} ; \mathrm{G}$ - media with $2 \mathrm{mg} / \mathrm{L}$ $\mathrm{BAP}$ and $0.5 \mathrm{mg} / \mathrm{L}$ IBA. Bar: $1 \mathrm{~cm}$ 
callus on a hormone-free medium led to active rhizogenesis without the formation of shoots.

When we cultivated young $B$. japonica seedlings on media containing a higher concentration of cytokinin (BAP or $\mathrm{Kn})$ than auxin (NAA or IBA), only direct regeneration of vegetative shoots on the surface of the outer scales was observed. In the case of the medium with $2 \mathrm{mg} / \mathrm{L} \mathrm{Kn}$ and $1 \mathrm{mg} / \mathrm{L} \mathrm{NAA}$, the shoot formation was weak and the development of roots and a noticeable increase in the size of the bulb occurred (Fig. 1C). Further explants cultivation on this medium was accompanied by a strong thickening of the roots without the formation of new shoots. Increasing the kinetin concentration to $10 \mathrm{mg} / \mathrm{L}$ and reducing NAA to $0.1 \mathrm{mg} / \mathrm{L}$ significantly stimulated the regeneration process and led to the appearance of numerous adventitious shoots on explants bulb surface (Fig. 1D).

Using of 6-benzylaminopurine even at a concentration of $2 \mathrm{mg} / \mathrm{L}$ in combination with $1 \mathrm{mg} / \mathrm{L} \mathrm{NAA}$ led to the intensive formation of young shoots on the bulb surface after 1.5 months of cultivation. Increasing the concentration of BAP to $4 \mathrm{mg} / \mathrm{L}$, or the replacement of NAA by IBA at a concentration of $0.5 \mathrm{mg} / \mathrm{L}$ also led to the active adventitious shoots formation (Fig. 1E-G).

To identify the most effective phytohormones combination for B. japonica micropropagation and counting of regenerated shoots, it was necessary to obtain plants with formed bulbs. According to Bang \& Choi (1996), regenerated from callus tissue plants of B. japonica were rooted easily without additional application of auxins and quickly acclimatized to ex vitro conditions. In our experiment, the obtained plants also were transferred to a hormone-free MS medium after 3 months of cultivation on propagation media (Fig. 2A,B). Shoots and roots active growth and the bulbs formation were observed after 2 months of the rooting stage without auxins utilization (Fig. 2C). In all cases the resulting plants were heterogeneous and bulbs varied in size from 2 to $8 \mathrm{~mm}$. The obtained results during the micropropagation experiment are shown in Table 1

\section{DISCUSSION}

Studies of some Scilla L. species morphogenesis in in vitro culture show that morphogenetic processes in different species are similar and do not depend on the type of explants. Subsequent emergence of meristematic foci and the formation of adventive structures occurs subepidermally from the abaxial side (McCartan \& van Staden 1998, Barykina \& Churikova 2001). Some authors note that leaf explants give a larger number of shoots compared to bulbous explants (McCartan \& van Staden 1998, Kamaleswari et al. 2016).

In accordance with previously published works, kinetin and its combinations with auxins are more effective for in vitro micropropagation of the genus Scilla L. representatives. Application of MS medium with $5 \mathrm{mg} / \mathrm{L} \mathrm{Kn}$ and $1 \mathrm{mg} / \mathrm{L} \mathrm{NAA}$ gave 12-14 shoots for $S$. byacinthiana leaf explants (Nair 1989). Using a mixture of $1-2 \mathrm{mg} / \mathrm{L}$ of kinetin with $1-2$ $\mathrm{mg} / \mathrm{L}$ indoleacetic acid (IAA) showed the best results for leaf (14.2 shoots per explant) and bulb explants (8.9 shoots per explant) for S. natalensis (McCartan \& van Staden 1998). Similar plant hormones combination also was more effective for S. kraussii leaf explants (McCartan \& van Staden 2002) and gave 6 shoots per explant. The combination of BAP and NAA was more effective for micropropagation of $S$. pratensis and S. autaminalis (Banciu et al. 2010, Balabova et al. 2013). Bulb explants of $S$. pratensis produced 5.2 shoots on medium with $2.25 \mathrm{mg} / \mathrm{L} \mathrm{BAP}$ and $0.93 \mathrm{mg} / \mathrm{L} \mathrm{NAA}$. Young seedlings of $S$. autaminalis gave 14.2 shoots when used combination of $5 \mathrm{mg} / \mathrm{L} \mathrm{BAP}$ and $1 \mathrm{mg} / \mathrm{L} \mathrm{NAA}$.

In our study it was found that the best phytohormones combinations which promote the most efficient micropropagation of Barnardia japonica were the following: $10 \mathrm{mg} / \mathrm{L}$ $\mathrm{Kn}+0.1 \mathrm{mg} / \mathrm{L}$ NAA (multiplication factor - 61.0), $2 \mathrm{mg} / \mathrm{L}$ $\mathrm{BAP}+0.5 \mathrm{mg} / \mathrm{L} \mathrm{IBA}$ (multiplication factor -47.0 ) and $4 \mathrm{mg} / \mathrm{L} \mathrm{BAP}+1 \mathrm{mg} / \mathrm{L} \mathrm{NAA}$ (multiplication factor - 46.6). The least effective combination for micropropagation by the direct regeneration method was the combination of $2 \mathrm{mg} / \mathrm{L} \mathrm{Kn}$ and $1 \mathrm{mg} / \mathrm{L} \mathrm{NAA}$ (multiplication factor

Table 1. The average number of shoots for Barnardia japonica micropropagation stage on MS medium with different phytohormones

\begin{tabular}{lc}
\hline Phytohormones combination & Average shoot number \\
\hline $1 \mathrm{mg} / \mathrm{L} 2,4-\mathrm{D}+0.5 \mathrm{mg} / \mathrm{L} \mathrm{BAP}$ & - \\
$2 \mathrm{mg} / \mathrm{L} \mathrm{NAA}+0.5 \mathrm{mg} / \mathrm{L} \mathrm{BAP}$ & $35.2 \pm 1.7$ \\
$2 \mathrm{mg} / \mathrm{LAP}+1 \mathrm{mg} / \mathrm{L} \mathrm{NAA}$ & $40.6 \pm 2.3$ \\
$4 \mathrm{mg} / \mathrm{LAP}+1 \mathrm{mg} / \mathrm{LAA}$ & $46.6 \pm 2.1$ \\
$2 \mathrm{mg} / \mathrm{LAP}+0.5 \mathrm{mg} / \mathrm{L} \mathrm{IBA}$ & $47.0 \pm 3.4$ \\
$2 \mathrm{mg} / \mathrm{L} \mathrm{Kn}+1 \mathrm{mg} / \mathrm{L} \mathrm{NAA}$ & $3.6 \pm 1.6$ \\
$10 \mathrm{mg} / \mathrm{L} \mathrm{Kn}+0.1 \mathrm{mg} / \mathrm{L} \mathrm{NAA}$ & $61.0 \pm 4.2$ \\
\hline
\end{tabular}
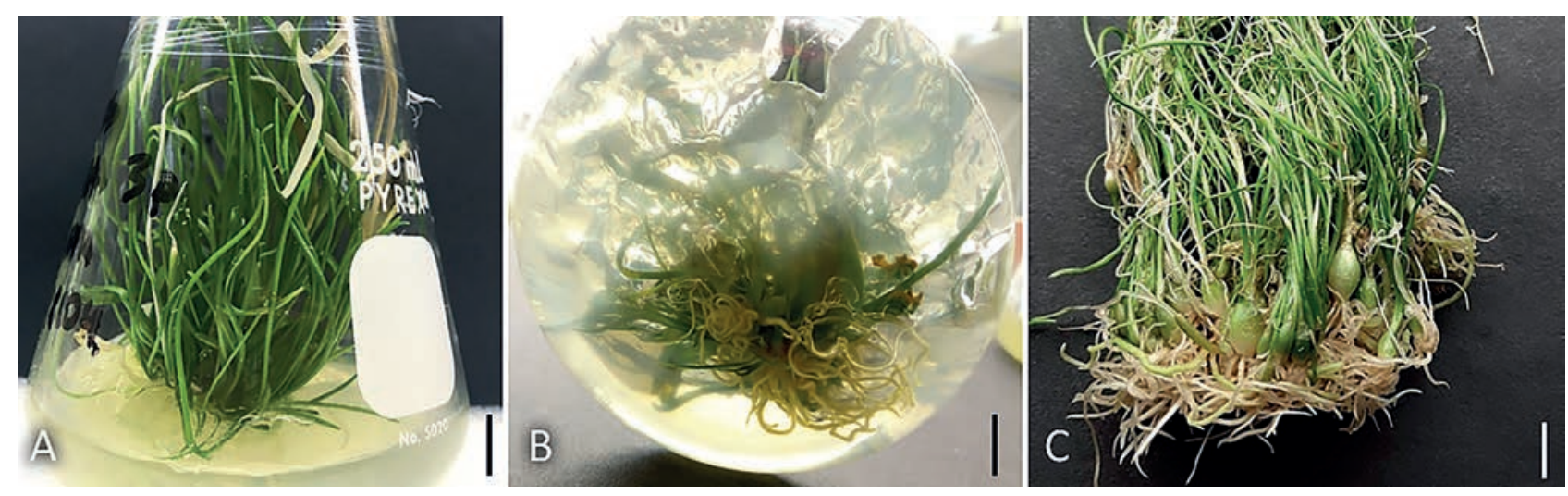

Figure 2 Development of Barnardia japonica plants at rooting stage (A, B) and after rooting stage (C). Bar: $1 \mathrm{~cm}$. 
- 3.6). The moderate multiplication rate showed media supplemented with $2 \mathrm{mg} / \mathrm{L} \mathrm{BAP}+1 \mathrm{mg} / \mathrm{L} \mathrm{NAA}$ (multiplication factor -40.6 ) and $2 \mathrm{mg} / \mathrm{L} \mathrm{NAA}+0.5 \mathrm{mg} / \mathrm{L}$ BAP (multiplication factor - 35.2). However, in the second case, the process of direct regeneration is associated with the formation of shoots from the resulting callus tissue. Rather high multiplication factor for B. japonica micropropagation in comparison with previously studied species can be explained by the use of young seedlings bulbs, which have significant regenerative potential in comparison with explants from adult plants.

\section{CONCLUSION}

Thus, it was shown that using MS media with a high concentration of cytokinins and low amount of auxins gives perfect results for threatened species Barnardia japonica reproduction by direct regeneration method in in vitro culture. The most effective combination is $10 \mathrm{mg} / \mathrm{L} \mathrm{Kn}+$ $0.1 \mathrm{mg} / \mathrm{L} \mathrm{NAA}$ (multiplication factor - 61.0). Good results also were obtained with $2 \mathrm{mg} / \mathrm{L} \mathrm{BAP}+0.5 \mathrm{mg} / \mathrm{L} \mathrm{IBA}$ (multiplication factor -47.0 ) and $4 \mathrm{mg} / \mathrm{L} \mathrm{BAP}+1 \mathrm{mg} / \mathrm{L}$ NAA (multiplication factor - 46.6). The collection of B. japonica plants in vitro is maintained in the active growth phase. Application of this micropropagation technique leads to the production of a large number of genetically homogeneous plants with a well-developed root system, suitable for ex vitro planting.

\section{ACKNOWLEDGEMENTS}

The work was carried out in accordance with the Botanical Garden-Institute FEB RAS state assignment № AAAA-A20-120042090002-0 on the project "Introduction and preservation of ex situ and in vitro genetic resources of East Asia plants".

\section{LITERAT URE CITED}

Banciu, C., M. Mitoi, F. Helepciuc \& F. Aldea 2010. In vitro propagation of critically endangered species Scilla autumnalis L. - biochemical analyses of the regenerants. Analele Universitatii din Oradea - Fascicula Biologie. 17(2):318-323.

Bang, J.W. \& H.W. Choi 1996. Somaclonal variation in Scilla scilloides complex. In: Somaclonal variation in crop improvement II. Biotechnology in agriculture and forestry, vol. 36 (Y.P.S. Bajaj, ed.), pp. 333-345, Springer, Berlin.

Balabova, D.V., L.I. Tikhomirova \& L.L. Sedelnikova 2013. Cultivating vegetative shoots Scilla pratensis Waldst. et Kit. by direct regeneration in bulb scales in culture in vitro. Izvestiya Altaiskogo Gosudarstvennogo Universiteta. Biologicheskie Nauki 3-1(79):15-18 (in Russian with English summary). [Балабова А.В., Тихомирова А.И., Седельникова $\Lambda . \Lambda$. 2013. Получение вегетативных побегов Scilla pratensis Waldst. et Kit. методом прямой регенерации у куковичных чешуй в культуре in vitro / / Известия Государственного А^тайского Университета. Биологические науки. Т. 3-1, № 79. С. 15-18].

Barkalov, V.Y. 2008. Scilla scilloides (Lindl.) Druce. In: The Red Data Book of the Russian Federation, plants and fungi (Yu.P. Trutnev et al., eds), pp. 144-145, KMK, Moscow (in Russian). [Баркалов В.Ю. 2008. Пролеска пролесковидная - Scilla scilloides (Lindl.) Druce // Красная книга Российской Федерации. Растения и грибы / под ред. Трутнева Ю.П. и Ар. Москва: Товарищество научных изАаний КМК, С. 287-288].
Barykina, R.P. \& O.A. Churikova 2001. The peculiarity of morphogenesis in some Scilla L. species in vitro. Vestnik Moskovskogo Universiteta. Seriya 16, biologiya 1:20-23 (in Russian with English summary) [Барыкина Р.П., Чурикова О.А. 2001. Особенности морфогенеза in vitro некоторых видов Scilla L. // Вестник Московского университета. Серия 16, биология. № 1. С. 20-23].

Butenko, R.G. 1999. Cell biology of higherplants in vitro and biotechnology on their base. FBK-PRESS, Moscow, 160 pp. (in Russian). [Бутенко Р.Г. 1999. Биология клеток высших растений in vitro и биотехнологии на их основе. Москва: ФБК-ПРЕСС, 160 с.].

Chakravarty, B. \& S. Sen 1989. Regeneration through somatic embryogenesis from anther explants of Scilla indica (Roxb.) Baker. Plant Cell, Tissue and Organ Culture 19(1):71-75.

Chaudhuri, D., \& S. Sen 2002. In vitro response of Scilla sibirica. Scientia Horticulturae 95:51-62.

Gontcharova, S.B., R.V.Doudkin \& M.N. Koldaeva 2010. On distribution of Barnardia japonica in the Russian Far East. Turczaninowia 13(4):23-27 (in Russian with English summary) [Гончарова С.Б., Аудкин Р.В., Колдаева М.Н. 2010. О распространении Barnardia japonica на российском Аальнем Востоке // Turczaninowia. T. 13, № 4. C. 23-27].

Kamaleswari, K., V. Nandagopalan \& A.L. Prabha 2016. Effects of plant growth regulators on in vitro regeneration of a potential medicinal plant Scilla byacinthina (Roth.) J.F. Macbr. Journal of Applied Biology and Biotechnology 4(1):43-46.

Kitagawa M. 1979. Neo-Lineamenta Florae Manshuricae. Vaduz, J. Cramer, 715 pp.

Lee T.B. 1993. Illustrated flora of Korea. Hyang Moon Sa, Seoul, 990 pp.

Lee Y.N. 1996. Flora of Korea. Kyo-Hak Publishing Co, Seoul, 1237 pp.

McCartan, S.A. \& J. van Staden 1998. Micropropagation of the medicinal plant Scilla natalensis Planch. Plant Growth Regulation 25:177-180.

McCartan, S.A. \& J. van Staden 1999. Micropropagation of members of the Hyacinthaceae with medicinal and ornamental potential - a review. South Afican Journal of Botany 65:361-369.

McCartan, S.A. \& J. van Staden 2002. Micropropagation of Scilla kraussii and Scilla dracomontana. South Afican Journal of Botany 68:223-225.

Murashige, T. \& F. Skoog 1962. A revised medium for rapid growth and bioassays with tobacco tissue cultutes. Phisiologia Plantarium 15(3):473-497.

Nair, A.S. 1989. Micropropagation of Scilla byacintbiana (Roth) Macbride. Proceedings of the Indian National Science Academy 55(2):121-124.

Ohwi J. 1965. Flora of Japan. Washington, Smitsonian Institution, $1067 \mathrm{pp}$.

Ozdemir, F.A., M.U. Yildirim, M.P. Kahriz \& O. Kilic 2016. In vitro bublet regeneration from Scilla siberica Haw. subsp. armena (Grossh.) Mordak peduncle. Propagation of Ornamental Plants 16(1):14-18.

Pshennikova, L.M., R.V. Doudkin \& L.N. Mironova 2019. New locality of Barnardia japonica (Hyacinthaceae) in the south of Primorye territory. Botanicheskii Zhurnal 104(11): 1765-1768 (in Russian) [Пшенникова А.М.,Аудкин Р.В., Миронова А.Н. 2019. Новое местонахождение редкого вила Barnardia japonica (Hyacinthaceae) на юге Приморского края / / Ботанический журнац. Т. 104, № 11. C. 1765-1768]. 